\title{
ANALISIS LAYANAN CALLNAK CENTRE DALAM PENGEMBANGAN USAHA TERNAK SAPI POTONG DI KOTA PAREPARE
}

\author{
Usman'), Andi Nuddin2), dan Sahabuddin Toaha3) \\ 1)Program Studi Kesehatan Masyarakat Universitas Muhammadiyah Parepare \\ 2,3)Program Studi Agribisnis Universitas Muhammadiyah Parepare \\ Jl. Jenderal Ahmad Yani KM 6, Kota Pare-Pare, Sulawesi Selatan, Indonesia \\ e-mail: 1)usman.health86.ud@gmail.com
}

(Diterima 11 Mei 2021 / Revisi 29 Mei 2021 / Disetujui 7 Juli 2021)

\begin{abstract}
Beef Cattle is one of the meat-producing resources that have great benefits for the fulfilment and improvement of community nutrition. The low population of Beef Cows is due to small scale of livestock production with limited land and capital. In addition, unpredictable weather may threaten the animal health. To carry out preventive activities against outbreaks of disease in livestock, the government has set up a program, namely CallNak Center. The research objective was to analyze the effect of animal health services, health status checks, and artificial insemination on the development of Beef Cattle. The research method used quantitative research with a cross-sectional study approach. The research was conducted in Parepare City from August 2020 to April 2021. The sampling technique used non-probability sampling with purposive sampling with a total sample of 73 breeders. The data analysis used in this study is the Chi-Square Test. The results showed that most respondents (76,71\%) felt the benefits of animal health services, and health status checks and respondents considered beneficial were 78,08\%. Meanwhile, respondents who felt the benefits of Artificial Insemination (IB) services were 50,68\% or only differed as 1,36\% who considered the program less useful. Respondents who stated that they had experienced the development of beef cattle since the CallNak Center was 82,19\%, while only 17,81\% suggested less developed. The results of the analysis showed that animal health services and health status checks have significant effects, meanwhile the artificial Insemination do not significantly affect the development of cattle in Parepare City.
\end{abstract}

Keywords: artificial insemination, animal health services, reproductive health checks, livestock development

ABSTRAK

Sapi Potong merupakan salah satu sumber penghasil daging yang memiliki banyak manfaat khususnya untuk pemenuhan gizi dan peningkatan gizi masyarakat. Salah satu penyebab rendahnya populasi Sapi Potong karena sebagian besar ternak dipelihara dalam skala kecil dengan lahan dan modal terbatas. Selain itu, cuaca yang tidak menentu mengancam kesehatan hewan. Untuk melakukan kegiatan pencegahan terhadap mewabahnya penyakit pada ternak maka pemerintah meluncurkan Program CallNak Centre. Tujuan penelitian adalah untuk menganalisis pengaruh layanan Kesehatan hewan, pemeriksaan status kesehatan reproduksi dan inseminasi buatan terhadap pengembangan ternak Sapi Potong. Metode penelitian ini menggunakan penelitian kuantitatif dengan pendekatan cross sectional study. Penelitian dilaksanakan di Kota Parepare mulai dari bulan Agustus 2020 sampai April 2021. Teknik pengambilan sampel menggunakan Non Probability Sampling dengan Purposive Sampling dengan jumlah sampel sebanyak 73 orang peternak. Analisis data yang digunakan dalam penelitian ini adalah Uji Chi-Square. Hasil penelitian, menunjukkan bahwa sebagian besar responden $(76,71 \%)$ merasakan manfaat dari layanan kesehatan hewan, dan pemeriksaan status Kesehatan dan reproduksi responden yang menyatakan bermanfaat sebesar 78,08\%. Sedangkan responden yang merasakan manfaat pelayanan Inseminasi Buatan (IB) sebesar 50,68\% atau hanya selisih 1,36\% yang menyatakan kurang bermanfaat. Responden yang menyatakan mengalami perkembangan ternak Sapi Potong sejak ada CallNak Centre sebanyak 82,19\% sedangkan yang menyatakan kurang berkembang hanya 17,81\%. Hasil analisis menunjukkan bahwa, layanan kesehatan hewan dan pemeriksaan status Kesehatan dan reproduksi berpengaruh secara nyata sedangkan Inseminasi Buatan tidak berpengaruh secara nyata terhadap pengembangan ternak Sapi Potong di Kota Parepare.

Kata kunci: inseminasi buatan, layanan kesehatan hewan, pemeriksaan kesehatan reproduksi, pengembangan ternak 


\section{PENDAHULUAN}

Pembangunan dalam bidang peternakan menjadi salah satu faktor yang menentukan pengembangan wilayah di Sulawesi Selatan. Hal tersebut disebabkan sebab peternakan mempunyai peranan yang strategis dalam menopang perekonomian masyarakat dan pembangunan sumberdaya manusia. Peranan tersebut dapat kita lihat dari berbagai fungsi produk hasil peternakan sebagai penyedia protein hewani yang sangat dibutuhkan untuk pertumbuhan dan perkembangan tubuh manusia. Selain itu, seiring dengan meningkatnya tingkat kesejahteraan masyarakat akan berdampak pada meningkatnya tingkat konsumsi masyarakat termasuk dalam mengkonsumsi hasil peternakan (Irmayani, 2013).

Provinsi Sulawesi Selatan pernah menempati urutan ketiga secara nasional sebagai daerah dengan populasi ternak terbanyak dan dinobatkan sebagai salah satu daerah dengan predikat lumbung ternak. Predikat tersebut membuat Sulsel mampu menjadi pemasok bibit sapi maupun sapi potong pada beberapa daerah yang ada di Kawasan Timur Indonesia (Arsad, 2017). Empat tahun terakhir, populasi Sapi Potong di Sulawesi Selatan memperlihatkan peningkatan yang signifikan yaitu pada tahun 2017 sebanyak 1.434.998 ekor, tahun 2018 sebanyak 1.535 .187 ekor, tahun 2019 sebanyak 2.235.109 ekor sedangkan pada tahun 2020 sebanyak 2.512.196 ekor.

Sapi Potong mempunyai peranan dan manfaat penting dalam pemenuhan kebutuhan gizi dan peningkatan gizi masyarakat serta menjadi salah satu sumber penghasil daging terbesar. Salah satu sumber protein hewani adalah daging sapi yang merupakan salah satu kebutuhan yang diperlukan dalam pemenuhan kebutuhan pangan dan gizi masyarakat. Peningkatan jumlah penduduk berdampak pada meningkatnya permintaan dan kebutuhan akan konsumsi daging pada masyarakat setiap tahunnya. Sehingga demikian, berternak Sapi Potong merupakan salah satu usaha yang sangat menjanjikan karena meningkatnya permintaan bahan pangan yang bersumber dari hewan khususnya sumber protein hewani termasuk daging (Arsad, 2017).
Populasi daging sapi secara nasional belum mampu memenuhi permintaan akan kebutuhan konsumsi daging sapi. Rendahnya populasi daging disebabkan karena rendahnya populasi Sapi Potong yang disebabkan karena mayoritas sapi potong dipelihara dalam skala kecil dengan jumlah lahan dan modal terbatas. Selain itu, cuaca yang tidak menentu atau peralihan musim dapat mengancam kesehatan termasuk juga kesehatan hewan. Saat musim pancaroba, banyak virus yang menyerang hewan ternak Coccidiosis atau berak darah, abortus, infeksi saluran pencernaan dan antrax (Wiedosari E dan Wahyuwardani S, 2015).

Beberapa cara yang dapat dilakukan untuk meningkatkan jumlah produksi anak sapi dan daging yaitu mendorong peningkatan jumlah pemilikan Sapi Potong dan perbaikan mutu genetik sapi. Hal tersebut dapat dilakukan dengan penerapan program Inseminasi Buatan (IB) pada Sapi Potong dengan memanfaatkan sapi jantan yang genetiknya baik dan angka servis per conception (S/C) (Nelly Kusrianty, Mirajuddin dan Awaluddin, 2016). Selain itu juga dapat ditempuh melalui mengefisienakan reproduksi Sapi Potong, karena reproduksi pada Sapi Potong memiliki hubungan yang erat dengan perkembangan jumlah Sapi Potong (Sugoro I, 2009)

Angka kematian ternak sapi pada tahun 2013 di Kota Parepare tergolong sangat tinggi yaitu $11,4 \%$ (524 ekor). Hal ini tidak diimbangi dengan jumlah pertumbuhan populasi yang hanya 6,3\% yang masih di bawah target di Provinsi Sulawesi Selatan sebesar 6-7\% pertumbuhan populasi. Salah satu penyebab rendahnya pertumbuhan populasi sapi potong yaitu penyakit Coccidiosis yang terjadi pada anak sapi sehingga berdampak pada sikap apatis peternak dan mempunyai risiko meluasnya wabah. Upaya Pencegahan penyakit harus menjadi perhatian serius untuk menghindari tingginya penularan penyakit pada sapi yang menghambat produktivitas sapi. Pencegahan penyakit pada sapi dapat dilaksanakan secara sederhana dengan cara menjaga higiene atau kebersihan sapi dan sanitasi atau kebersihan kandang serta secara rutin melakukan vaksinasi. Pengobatan pada Sapi Potong dilaksanakan setelah dilakukan diagnosis akan jenis penyakit yang menyerang sapi tersebut. Hasil diagnosis kemudian dilakukan pengobatan 
secara cepat dan tepat untuk menghindari kematian pada Sapi Potong.

Upaya yang dapat dilaksanakan oleh pemerintah dalam penanganan ternak Sapi potong di Kota Parepare yaitu peluncuran suatu program CallNak Centre. CallNak Centre merupakan wadah untuk menerima aduan dan respons cepat masalah peternakan dan kesehatan hewan. CallNak Centre adalah pelayanan mobile yang intens selama 1x24 jam meliputi semua jenis ternak. Tujuan CallNak Centre adalah peningkatan status kesehatan ternak pada umumnya dan perbaikan mutu genetik ternak sapi (Wali kota Parepare, 2019).

Sacara garis besar, jenis layanan CallNak Centre yaitu layanan kesehatan hewan, pemeriksaan status kesehatan dan reproduksi dan Inseminasi Buatan. Callnak Centre memiliki sasaran untuk pemberian layanan baik layanan kesehatan hewan, pemeriksaan status kesehatan dan reproduksi maupun Inseminasi Buatan. sebanyak 1.019 ternak. Dari 1.019 sasaran, ternak yang telah mendapatkan layanan kesehatan hewan dalam hal ini pencegahan dan pengobatan baru 497 ternak dan ternak yang telah mendapatkan pemeriksaan status kesehatan reproduksi sebanyak 262 ternak. Sedangkan ternak yang mendapatkan kegiatan Inseminasi Buatan baru 104 ternak (Dinas PKP Kota Parepare).

CallNak Centre merupakan inovasi kedua di Kota Parepare yang berhasil masuk dalam Top 99 Pelayanan Publik. Salah satu pertanyaan yang menarik adalah apakah predikat tersebut mencerminkan pelayanan yang baik pada masyarakat sehingga dapat berkontribusi terhadap pengembangan usaha ternak Sapi Potong di Kota Parepare (Kementerian PAN-RB, 2019)

Berdasarkan uraian di atas, maka tujuan penelitian adalah, (1) menganalisis pengaruh layanan Kesehatan hewan terhadap pengembangan ternak Sapi Potong; (2) menganalisis pengaruh pemeriksaan status kesehatan reproduksi terhadap pengembangan ternak Sapi Potong; (3) menganalisis pengaruh inseminasi buatan terhadap pengembangan ternak Sapi Potong.

\section{METODE}

\section{LOKASI PENELITIAN}

Penelitian dilakukan di Kota Parepare dengan kriteria atau pertimbangan bahwa Kota Parepare adalah satu-satunya daerah yang memiliki kebijakan dan Program dalam pelayanan kesehatan hewan secara mobile 24 jam yaitu CallNak Centre di Indonesia. Pelaksanaan penelitian pada dari bulan Agustus 2020 sampai April 2021.

\section{BENTUK PENELITIAN}

Metode penelitian ini menggunakan penelitian kuantitatif yang bersifat analitik dengan pendekatan cross sectional yang bertujuan untuk mengethui pengaruh layanan CallNak Centre terhadap pengembangan ternak Sapi Potong baik dari aspek pelayanan kesehatan hewan, pemeriksaan status kesehatan reproduksi dan Inseminasi Buatan. Penelitian kuantitatif yaitu suatu metode untuk mendapatkan suatu pengetahuan dengan memanfaatkan data berupa angka sebagai alat untuk melakukan analisis keterangan tentang apa yang ingin dipahami (Radjab dan Jam'an, 2017).

\section{METODE PENENTUAN SAMPEL}

Populasi yang terdapat pada penelitian yaitu seluruh peternak Sapi Potong di Kota Parepare yaitu sebanyak 276 orang (Dinas PKP Kota Parepare, 2019). Teknik pengambilan sampel yaitu Non Probability Sampling dengan dengan purposive sampling. Metode pengambilan sampel yang digunakan adalah purposive sampling atau biasa juga disebut dengan judgmental sampling yaitu teknik penentuan lokasi atau sampel penelitian sesuai dengan keinginan peneliti atas beberapa pertimbangan (Priyono, 2008). Adapun pertimbangan peneliti dalam memilih sampel, sebagai berikut: (1) Memiliki ternak Sapi Potong minimal 1 tahun; (2)Pernah menggunakan layanan CallNak Centre;

(3)Bersedia Menjadi Responden

Penentuan besar pengambilan sampel menggunakan rumus Slovin:

$$
\mathrm{n}=\frac{\mathrm{N}}{1+\mathrm{N}\left(\mathrm{d}^{2}\right)}
$$


Jadi jumlah sampel dalam penelitian ini sebanyak 73 orang peternak Sapi Potong.

\section{METODE ANALISIS DATA}

Seluruh data yang diperoleh kemudian diolah menggunakan perangkat lunak Program Microsoft Excel dan Program Statistical Product and Service Solutions (SPSS) versi 21 for windows. Hasil pengolahan didistribusikan dalam tabel distribusi disertai narasi hasil analisis dan interpretasi

Sedangkan analisis data yang digunakan untuk menguji pengaruh antara variabel terikat (dependen) dan variabel bebas (independen) adalah uji Chi-Square (regresi logistik) dengan rumus :

$$
x^{2}=\frac{\sum(\mathrm{fo}-\mathrm{fe})^{2}}{\mathrm{fe}}
$$

Keterangan:

$x^{2}$ : Nilai chi square

Fe : Frekuensi yang diharapkan

Fo : Frekuensi yang di observasi melalui pengamatan dan hasil kuesioner

\section{HASIL DAN PEMBAHASAN}

Pada tahap ini dilakukan analisis deskriptif kuantitatif baik variabel layanan kesehatan hewan, pemeriksaan status Kesehatan dan reproduksi, Inseminasi Buatan dan pengembangan ternak Sapi Potong yang disajikan dalam bentuk tabel distribusi frekuensi persentase sebagai berikut.

Data pada Tabel 1 menunjukkan mayoritas responden merasakan manfaat dari layanan kesehatan hewan yaitu sebesar 76,71\% dan hanya $23,29 \%$ yang menyatakan layanan kesehatan hewan kurang bermanfaat. Peternak sangat merasakan manfaat dengan adanya layanan kesehatan hewan. Beberapa pelayanan yang dianggap sangat bermanfaat antara lain, (1) Pelayanan pemeriksaan kesehatan maupun pengobatan berdasarkan indikasi kasus penyakit sesuai laporan masyarakat yang cepat; (2) Pelayanan vaksinasi yang diberikan oleh petugas sangat membatu peternak dalam pencegahan dan pengendalian penyakit ternak Sapi Potong di Kota Parepare.

Sedangkan pemeriksaan status Kesehatan dan reproduksi responden yang menyatakan bermanfaat sebesar 78,08\% dan yang menyatakan kurang bermanfaat sebesar 21,92\%. Beberapa indikator bahwa pemeriksaan kesehatan reproduksi bermanfaat dalam pengembangan ternak yaitu adanya layanan konsultasi dan pemeriksaan kondisi kesehatan saluran reproduksi serta pelayanan pemeriksaan kebuntingan baik pada ternak akseptor IB maupun akseptor kawin alam.

Sedangkan responden yang merasakan manfaat pelayanan Inseminasi Buatan (IB) sebesar 50,68\% atau hanya selisih 1,36\% yang menyatakan kurang bermanfaat yaitu 49,32\%. Ada beberapa penyebab kurangnya kemanfaatan

Tabel 1. Distribusi Responden Berdasarkan Manfaat Layanan Kesehatan Hewan, Manfaat Pemeriksaan Status Kesehatan dan Reproduksi, Manfaat Inseminasi Buatan dan Pengembangan Ternak Sapi Potong.

\begin{tabular}{lcc}
\hline \multicolumn{1}{c}{ Variabel } & Frekuensi (f) & $\mathbf{\%}$ \\
\hline Layanan Kesehatan Hewan & 56 & 76,71 \\
Bermanfaat & 17 & 23,29 \\
Kurang Bermanfaat & 57 & 78,08 \\
\hline Pemeriksaan Status Kesehatan dan Reproduksi & 21,92 \\
Bermanfaat & 16 & 50,68 \\
Kurang Bermanfaat & 37 & 49,32 \\
\hline Inseminasi Buatan & 36 & 82,19 \\
Kermanfaat & & $\mathbf{1 7 , 8 1}$ \\
\hline Pengembangan Ternak Sapi Potong & 60 & $\mathbf{1 0 0 , 0}$ \\
Berkembang & 13 & \\
\hline Kurang Berkembang & $\mathbf{7 3}$ & \\
\hline
\end{tabular}


yang dirasakan oleh peternak terhadap kegiatan IB yaitu Waktu birahi ternak betina yang tidak terkontrol, Kurangnya pengetahuan peternak dalam mendeteksi birahi, Pelaksanaan IB kurang berdampak pada penambahan jumlah populasi ternak, Kegiatan IB kurang maksimal dalam peningkatan jumlah ternak dan Sosialisasi dan edukasi dari tenaga kesehatan hewan kurang maksimal sehingga masyarakat kurang memahami keunggulan dari program IB.

Responden yang menyatakan mengalami perkembangan ternak Sapi Potong sejak ada CallNak Centre sebanyak 82,19\% sedangkan yang menyatakan kurang berkembang hanya 17,81\%. Indikator berkembangnya usaha ternak sapi potong dilihat dari penambahan jumlah/populasi ternak dan jumlah anggota kelompok ternak.

\section{PENGARUH LAYANAN KESEHATAN HEWAN TERHADAP PENGEMBANGAN TERNAK SAPI POTONG DI KOTA PAREPARE}

Berdasarkan hasil analisis Chi-Square, Pengaruh layanan Kesehatan hewan terhadap pengembangan ternak Sapi Potong dapat dilihat pada Tabel 2 .

Hasil penelitian menunjukkan bahwa usaha ternak Sapi Potong yang mengalami perkembangan sebagian besar peternak menganggap layanan kesehatan hewan bermanfaat dibanding yang menganggap kurang bermanfaat, sedangkan usaha ternak Sapi Potong kurang berkembang sebagian besar menganggap bahwa layanan Kesehatan hewan kurang bermanfaat dan yang menyatakan bermanfaat hanya. Berdasarkan hasil uji chi-square diperoleh nilai $\mathrm{p}=0,009$, lebih kecil dibandingkan dengan $\alpha(0,05)$ dengan demikian maka Ha di terima dan Ho ditolak dengan kesimpulan bahwa ada pengaruh layanan kesehatan hewan terhadap pengembangan ternak Sapi Potong di Kota Parepare.

Masyarakat khususnya peternak sangat merasakan manfaat dengan adanya layanan kesehatan hewan yang diberikan oleh Callnak Centre Kota Parepare. Callnak Centre telah memberikan pelayanan yang cepat khususnya dalam pelayanan pemeriksaan kesehatan maupun pengobatan berdasarkan indikasi kasus penyakit sesuai laporan masyarakat. Selain itu, pelayanan vaksinasi yang diberikan oleh petugas Callnak Centre sangat membatu peternak dalam pencegahan dan pengendalian penyakit ternak Sapi Potong di Kota Parepare. Secara umum, layanan Kesehatan hewan memberikan pengaruh yang nyata terhadap pengembangan ternak, namun demikian juga ditemuakn bahwa masih ada masyarakat yang belum pernah menggunakan layanan Callnak Centre. Hal ini disebabkan karena sebagian kecil peternak tergolong masih baru dan tidak berafiliasi dengan salah satu kelompok tani ternak dan informasi tentang keberadaan layanan Callnak Centre belum diketahui oleh seluruh peternak di Kota Parepare.

Hasil penelitian ini didukung dengan hasil penelitian yang menunjukkan bahwa kesuksesan usaha ternak Sapi Potong, baik penggemukan (fattening) maupun penghasil bibit (breeding), dipengaruhi oleh kondisi kesehatan ternak tersebut. Hal ini mengindikasikan bahwa pencegahan dan penanganan penyakit harus menjadi skala prioritas. Kesehatan ternak adalah tujuan utama dalam melaksanakan usaha ternak Sapi Potong, baik jumlah besar maupun dalam jumlah kecil. pencegahan dan Penanganan penyakit ternak utamanya Sapi Potong membutuhkan perhatian dari segala aspek, baik aspek penyakit maupun aspek ekonomis (Fitri S, 2015).

Tabel 2. Pengaruh Layanan Kesehatan Hewan Terhadap Pengembangan Ternak Sapi Potong di Kota Parepare

\begin{tabular}{|c|c|c|c|c|c|c|c|}
\hline \multirow{3}{*}{$\begin{array}{l}\text { Pelaksanaan Layanan } \\
\text { Kesehatan Hewan }\end{array}$} & \multicolumn{4}{|c|}{$\begin{array}{c}\text { Pengembangan } \\
\text { Usaha Ternak Sapi Potong }\end{array}$} & \multirow{2}{*}{\multicolumn{2}{|c|}{ Total }} & \multirow{3}{*}{ Hasil Uji } \\
\hline & \multicolumn{2}{|c|}{ Berkembang } & \multicolumn{2}{|c|}{$\begin{array}{c}\text { Kurang } \\
\text { Berkembang }\end{array}$} & & & \\
\hline & f & $\%$ & f & $\%$ & $\mathbf{f}$ & $\%$ & \\
\hline Bermanfaat & 50 & 68,49 & 6 & 8,22 & 56 & 76,71 & \multirow{2}{*}{0,009} \\
\hline Kurang Bermanfaat & 10 & 13,70 & 7 & 9,59 & 17 & 23,29 & \\
\hline Jumlah & 60 & 82,19 & 13 & 17,81 & 73 & 100,0 & \\
\hline
\end{tabular}




\section{PENGARUH PEMERIKSAAN STATUS KESEHATAN DAN REPRODUKSI TERHADAP PENGEMBANGAN TERNAK SAPI POTONG DI KOTA PAREPARE}

Berdasarkan hasil penelitian di lapangan, Pengaruh pemeriksaan status Kesehatan dan reproduksi terhadap pengembangan ternak Sapi Potong di Kota Parepare dapat dilihat pada Tabel 3.

Hasil penelitian menunjukkan bahwa usaha ternak Sapi Potong yang mengalami perkembangan sebagian besar menganggap bahwa pemeriksaan status Kesehatan dan reproduksi bermanfaat dibanding yang menganggap kurang bermanfaat, sedangkan usaha ternak Sapi Potong kurang berkembang sebagian besar menganggap bahwa pemeriksaan status Kesehatan dan reproduksi kurang bermanfaat dan yang menyatakan bermanfaat hanya. Berdasarkan hasil uji chisquare diperoleh nilai $p=0,005$, lebih kecil dibandingkan dengan $\alpha(0,05)$ dengan demikian maka Ha di terima dan Ho di tolak dengan kesimpulan bahwa ada pengaruh pemeriksaan status Kesehatan dan reproduksi ta terhadap pengembangan ternak Sapi Potong di Kota Parepare.

Peternak sangat merasakan manfaat adanya layanan pemeriksaan status kesehatan dan reproduksi ternak Sapi Potong yang diberikan oleh Callnak Centre Kota Parepare. Beberapa hal yang menjadi dasar peternak sepakat bahwa pemeriksaan kesehatan reproduksi bermanfaat dalam pengembangan ternak yaitu adanya layanan konsultasi dan pemeriksaan kondisi kesehatan saluran reproduksi baik pada akseptor KB maupun kawin alam. Selain itu, Callnak Centre memberikan pelayanan pemeriksaan kebuntingan baik pada ternak akseptor IB maupun akseptor kawin alam.

Hasil penelitian ini didukung dengan hasil penelitian yang dialksanakan oleh Aikal pohontu, Agustinus Lomboan, Jantje F. Paath, Siane C. Rimbing. (2018) yang mengatakan bahwa penanganan reproduksi memiliki pengaruh terhadap tingkat produktivitas ternak yang diternakkan. Pemeriksaan Kesehatan reproduksi yang optimal dan berkesinambungan akan memberikan peningkatan performa reproduksi yang baik sehingga berdampak pada peningkatan jumlah kelahiran hewan ternak. Gangguan reproduksi umumnya terjadi disebabkan oleh manajemen pemeliharaan yang tidak optimal terutama pemberian pakan dan penyakit

\section{PENGARUH INSEMINASI BUATAN (IB) TERHADAP PENGEMBANGAN TERNAK SAPI POTONG DI KOTA PAREPARE}

Berdasarkan hasil penelitian di lapangan, pengaruh Inseminasi Buatan (IB) terhadap pengembangan ternak Sapi Potong di Kota Parepare dapat dilihat pada Tabel 4.

Hasil penelitian menunjukkan bahwa usaha ternak Sapi Potong yang mengalami perkembangan sebagian besar menganggap bahwa Inseminasi Buatan bermanfaat dibanding yang

Tabel 3. Pengaruh Pemeriksaan Status Kesehatan dan Reproduksi Terhadap Pengembangan Ternak Sapi Potong di Kota Parepare

\begin{tabular}{|c|c|c|c|c|c|c|c|}
\hline \multirow{3}{*}{$\begin{array}{c}\text { Pelaksanaan } \\
\text { Pemeriksaan Status } \\
\text { Kesehatan dan } \\
\text { Reproduksi }\end{array}$} & \multicolumn{4}{|c|}{ Pengembangan Usaha Ternak Sapi Potong } & \multirow{2}{*}{\multicolumn{2}{|c|}{ Total }} & \multirow{3}{*}{ Hasil Uji } \\
\hline & \multicolumn{2}{|c|}{ Berkembang } & \multicolumn{2}{|c|}{ Kurang Berkembang } & & & \\
\hline & f & $\%$ & $\mathbf{f}$ & $\%$ & $\mathbf{f}$ & $\%$ & \\
\hline Bermanfaat & 51 & 69,86 & 6 & 8,22 & 57 & 78,08 & \multirow{2}{*}{0,005} \\
\hline$\underline{\text { Kurang Bermanfaat }}$ & 9 & 12,33 & 7 & 9,59 & 16 & 21,92 & \\
\hline Jumlah & 60 & 82,19 & 13 & 17,81 & 73 & 100,0 & \\
\hline
\end{tabular}

Tabel 4. Pengaruh Inseminasi Buatan (IB) Terhadap Pengembangan Ternak Sapi Potong di Kota Parepare

\begin{tabular}{|c|c|c|c|c|c|c|c|}
\hline \multirow{3}{*}{$\begin{array}{l}\text { Pelaksanaan Kegiatan } \\
\text { Inseminasi Buatan (IB) }\end{array}$} & \multicolumn{4}{|c|}{ Pengembangan Usaha Ternak Sapi Potong } & \multirow{2}{*}{\multicolumn{2}{|c|}{ Total }} & \multirow{3}{*}{ Hasil Uji } \\
\hline & \multicolumn{2}{|c|}{ Berkembang } & \multicolumn{2}{|c|}{ Kurang Berkembang } & & & \\
\hline & $\mathbf{f}$ & $\%$ & $\mathbf{f}$ & $\%$ & $\mathbf{f}$ & $\%$ & \\
\hline Bermanfaat & 32 & 43,83 & 5 & 6,85 & 37 & 50,68 & \\
\hline Kurang Bermanfaat & 28 & 38,36 & 8 & 10,96 & 36 & 49,32 & 3 \\
\hline Jumlah & 60 & 82,19 & 13 & 17,81 & 73 & 100,0 & \\
\hline
\end{tabular}


menganggap kurang bermanfaat, sedangkan usaha ternak Sapi Potong kurang berkembang sebagian besar menganggap bahwa Inseminasi Buatan kurang bermanfaat dan yang menyatakan bermanfaat hanya. Berdasarkan hasil uji chisquare diperoleh nilai $p=0,253$, lebih kecil dibandingkan dengan $\alpha(0,05)$ dengan demikian maka $\mathrm{Ha}$ di terima dan Ho di tolak dengan kesimpulan tidak ada pengaruh Inseminasi Buatan terhadap pengembangan ternak Sapi Potong di Kota Parepare.

Beberapa aspek yang menyebabkan kegagalan tersebut antara lain sistem penggembalaan ternak yang dilakukan secara bebas sehingga dimungkikan terjadi kawin alam dan juga waktu birahi yang tidak terkontrol dan kurangnya informasi atau pengetahuan peternak dalam melakukan deteksi birahi sehingga berdampak pada keterlambatan dilakukan Inseminasi Buatan. Kurangnya pengetahuan masyarakat juga berdampak kurangnya masyarakat yang menerima program Inseminasi Buatan dan memilih mengandalkan pejantan dalam proses kawin alam ternak mereka. Nilai koefisien regresi pengalaman beternak adalah sebesar $-0,007$ yang artinya setiap peningkatan pengalaman beternak sebesar 1 tahun, maka akan menurunkan penggunaan IB sebesar $0,7 \%$ dengan asumsi bahwa faktor lainnya tetap (Suteja DK, 2020)

Tidak adanya pengaruh Inseminasi Buatan terhadap pengembangan ternak Sapi Potong juga diperkuat oleh pernyataan responden kalau program tersebut kurang memberi manfaat terhadap pengembangan ternak Sapi Potong. Hal ini disebabkan karena banyaknya peternak yang pernah mendapatkan layanan Inseminasi Buatan terhadap ternak mereka namun tidak berhasil. Pelaksanaan program Inseminasi Buatan tidak memberikan dampak yang signifikan pada peningkatan populasi Sapi Potong, namun disisi lain program Inseminasi Buatan telah memberikan kontribusi positif khususnya pada peningkatan kualitas genetik.

Hasil penelitian ini diperkuat hasil penelitian Sabran (2015) yang meyatakan bahwa Inseminasi Buatan tidak berpengaruh nyata terhadap Calving Interval/jarak beranak dalam peningkatan populasi Sapi Potong di Kecamatan Gantarangkeke. Hasil ini tidak diperkuat oleh penelitian Marthin Sibagariang, Zulkarnain Lubis, Hasnudi Hasnudi (2010) yang menyatakan bahwa mayoritas responden setuju Inseminasi Buatan (IB) dapat meningkatkan produktivitas.

Metode penyimpanan semen beku masih terdapat kelemahan dari segi manajemen yang disebabkan oleh kurangnya kemampuan inseminator maupun keterbatasan fasilitas yang tersedia. Secara umum, peternak telah menerima program inseminasi buatan akan tetapi masih kurang peternak yang mau memanfaatkan layanan tersebut, bahkan tingkat keberhasilan penggunaan inseminasi buatan masih sangat kecil (Sawo K. 2017). Mayoritas peternak lebih memilih memanfaatkan teknik kawin alami untuk ternak sapi mereka disbanding menggunakan program IB. Hal ini disebabkan karena tingkat kepercayaan masyarakat pada program IB masih rendah (Nurlaila. S., Kurnadi. B, Zali. M, dan Nining H, 2018)

Keberhasilan pelaksanaan program IB dipengaruhi oleh beberapa faktor yang saling terintegrasi dan harus dilakukan secara kolektif antara lain 1). keterampilan inseminator; 2). kualitas semen; 3). akurasi deteksi; 4). pemilihan sapi akseptor. Selain itu, Keberhasilan program IB tergantung pada sikap dan kemauan peternak akan tetapi tetap dibutuhkan kemampuan petugas dan kebijakan pemerintah daerah.

\section{SIMPULAN DAN SARAN}

\section{SIMPULAN}

Berdasarkan hasil penelitian dan pembahasan maka dapat disimpulkan sebagai berikut:

1. Layanan Kesehatan hewan berpengaruh terhadap pengembangan ternak Sapi Potong karena peternak sangat merasakan manfaat keberadaan Callnak Centre dan berkontribusi dalam pengembangan ternak Sapi potong.

2. Pemeriksaan status kesehatan reproduksi berpengaruh terhadap pengembangan ternak Sapi Potong karena kegiatan tersebut sangat membantu peternak dalam mencegah dan mendeteksi sejak dini gangguan kesehatan reproduksi ternak.

3. Inseminasi buatan tidak berpengaruh terhadap pengembangan ternak Sapi Potong karena sebagian besar program IB yang dilakukan kepada ternak tidak berhasil 


\section{SARAN}

Berdasarkan hasil penelitian dan pembahasan maka dapat dirumuskan saran sebagai berikut:

1. Pemerintah diharapkan meningkatkan pelayanan Callnak Centre khususnya untuk pelayanan Inseminasi Buatan baik pemilihan sapi akseptor, akurasi deteksi birahi dan keterampilan inseminator sehingga program tersebut dapat bermanfaat untuk peternak dalam pengembangan ternak Sapi Potong.

2. Pemerintah Kota Parepare dalam hal ini Dinas Pertanian, Kelautan dan Perikanan diharapkan melakukan sosialisasi dan edukasi kepada masyarakat berkaitan dengan fungsi dan peran Callnak Centre secara maksimal.

3. Masyarakat diharapkan memanfaatkan layanan Callnak Centre baik layanan kesehatan hewan, pemeriksaan Kesehatan reproduksi dan Inseminasi Buatan untuk meningkatkan atau mengembangkan usaha ternak Sapi Potong mereka.

\section{DAFTAR PUSTAKA}

Aikal pohontu, Agustinus Lomboan, Jantje F. Paath, Siane C. Rimbing. 2018. Penampilan Reproduksi Ternak Sapi Potong di Kecamatan Bintauna Kabupaten Bolaang Mengondow Utara. Jurnal Zootek. ISSN:08522626. Volume 38, Nomor 1, Januari 2018.

Arsad. 2017. Analisis Potensi Wilayah untuk Pengembangan Usaha Ternak Sapi Potong di Kecamatan Bontotiro Kabupaten Bulukumba. [skripsi] UIN Alauddin. Makassar

Fitri S. 2015. Analisis Manajemen Kesehatan terhadap Produktivitas Ternak Sapi Potong di PT. Berdikari United Livestock (BULS) Kabupaten Sidrap. [skripsi] UIN Alauddin. Makassar.

Irmayani. 2013. Analisis Tingkat Motivasi Peternak Sapi Perah di Kabupaten Enrekang dan Faktor yang Mempengaruhinya. [tesis] Universitas Hasanuddin. Makassar.

Kementerian PAN-RB, 2019. CallNak Centre, Inovasi yang Mudahkan Peternak Atasi Penyakit Hewan. https://www.menpan.go.id/site/berita- terkini/callnak-centre-inovasi-yangmudahkan-peternak-atasi-penyakit-hewan. Diakses tanggal 10 Juli 2020.

Marthin Sibagariang, Zulkarnain Lubis, Hasnudi Hasnudi. 2010. Analisis pelaksanaan Inseminasi Buatan (IB) pada sapi dan strategi pengembangannya di Provinsi Sumatera Utara. Agrica (Jurnal Agribisnis Sumatera Utara) Vol.3 No.2/Oktober 2010.

Nelly Kusrianty, Mirajuddin dan Awaluddin, 2016. Efektivitas Inseminasi Buatan Pada Sapi Potong Menggunakan Semen Cair. E-Jurnal Mitra Sains, Vol. 4, Nomor 1, januari 2016.

Nurlaila. S., Kurnadi. B, Zali. M, dan Nining H. 2018. Status Reproduksi Dan Potensi Sapi Sonok di Kabupaten Pamekasan. Jurnal Ilmiah Peternakan Terpadu Vol. 6(3): 147154, November 2018.

Priyono. 2008. Metode Penelitian Kuantitatif. Zifatama Publishing. Sidoarjo.

Radjab E, Jam'an A. 2017. Metodologi Penelitian Bisnis. Lembaga Perpustakaan dan Penerbitan Unismuh. Makassar.

Sawo K. 2017. Evaluasi Efisiensi Reproduksi Ternak Sapi Bali Betina Di Distrik Makimi. Jurnal Fapertanak. Volume 2 Nomor 2, November 2017.

Sugoro, I. 2009. Pemanfaatan Inseminasi Buatan Untuk Meningkatkan Produktivitas Sapi. Bandung: Kajian Bioetika Institut Teknologi Bandung.

Suteja DK, 2020. Analisis Faktor-Faktor Yang Mempengaruhi Peternak Sapi Potong Terhadap Intensitas Penggunaan Inseminasi Buatan Di Kecamatan Kendit Kabupaten Situbondo. Jurnal Ilmiah AGRIBIOS. Vol. 18, No. 1, Juni 2020.

Wali kota Parepare. Peraturan Wali kota Parepare Nomor 26 Tahun 2009 tentang Pedoman Pelayanan CallNak Centre. Parepare

Wiedosari E dan Wahyuwardani S. 2015. Studi Kasus Penyakit Ayam Pedaging di Kabupaten Sukabumi dan Bogor. Jurnal Kedokteran Hewan. Vol. 9, No. 1, Maret 2015. [BPS]Badan Pusat Statistik., 2014-2017. Produksi Tanaman Hortikultura (paprika). Tabel Dinamis. 